\title{
Fish Protein and Its Derivatives: Functionality, Biotechnology and Health Effects
}

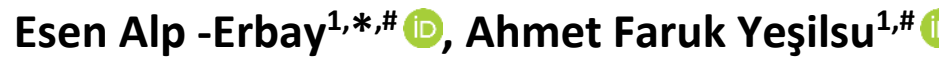 \\ ${ }^{1}$ Central Fisheries Research Institute, Vali Adil Yazar Cad. No:14, Kaşüstü, Trabzon, Turkey \\ \#These authors share the first authorship.
}

\section{How to cite}

Alp -Erbay, E., Yeşilsu, A.F., (2021). Fish Protein and Its Derivatives: Functionality, Biotechnology and Health Effects. Aquatic Food Studies, 1(1), AFS13. https://doi.org/10.4194/AFS13

\section{Article History}

Received 15 May 2021

Accepted 25 June 2021

First Online 01 July 2021

\section{Corresponding Author \\ Tel.: +904623411053 \\ E-mail: esen.alp@tarimorman.gov.tr yesilsu@gmail.com}

\section{Keywords}

Myofibrillar proteins

Nitrogenous compounds

Processing methods

Sarcoplasmic proteins

\begin{abstract}
Animal derived proteins provide the essential amino acid requirements of a healthy diet. Among animal proteins, fish proteins have a well-balanced amino acid composition that are imperative for beneficial synthesizing and utilizing proteins in the body. Lack or low levels of any amino acid reduce the other amino acid utilization proportionately. This is why plant-derived proteins are potentially at a disadvantage for use in the body since they have relatively low levels of the essential amino acids methionine and lysine. Health studies have revealed that fish protein is suggested as a weight-loss diet to obese patients.
\end{abstract}

\section{Introduction}

Fish consumption reached to $20 \mathrm{~kg}$ per capita in 2014 in the world. Significant growth of fish consumption has significant effects on the diets of people in terms of health issues. Fish consumption was only about 17 percent of animal protein intake for the global population and 6.7 percent of all protein sources in 2013. Fish has easily digestible high-quality proteins with essential amino acids and also includes fatty acids (i.e., omega-3 fatty acids) and essential vitamins and minerals like $A, B, D$ and calcium, selenium, zinc, iodine, iron respectively (FAO, 2020). Fish have well-balanced amino acid composition in their protein structure (Harnedy \& FitzGerald, 2012) constitute an important source of animal protein in the diet of many populations in the coastal areas. Human provide large part of the essential amino acid requirements from fresh, salted, dried and fermented fish products (Tamang, 2015; Majumdar et al., 2016).

In general, fish include mainly lipids, water and proteins with the minor components such as nonprotein nitrogenous compounds and carbohydrates, minerals and vitamins. According to FAO, a fresh fish fillet has usually about 66-81 percent of $(\mathrm{w} / \mathrm{w})$ water, 16-21 percent of protein and widely ranged fat content depending on the feeding of the fish (URL-1). Fish is classified into two categories depending on their most important components, protein and fat. Two groups, medium fat high protein, low fat high protein and 
comprise the most common types of fish and have protein contents from $15-20 \%$ in the edible parts of the fish (Finch \& Liston, 1970). The fish protein can be classified into three groups according to FAO, 1) Structural proteins such as, actin, myosin, tropomyosin and actomyocin with a $70-80 \%$ proportion in total protein content 2) sarcoplasmic proteins such as myoalbumin, globulin and enzymes with a 25-30\% proportion 3) connective tissue protein such as collagen; $3 \%$ proportion in teleostei and $10 \%$ in elasmobranchii) (URL-1).

Composition of the fish vary greatly between and within the species depending on the catch season, maturity and location where the protein content remains relatively constant and water and fat content alter. The crude protein content with contribution of non-protein nitrogenous (NPN) compounds like free amino acids, polyamines, peptides, nucleotides of fish, crustaceans and mollusks is slightly up to percentage 1127 (Shahidi \& Simpson, 2004). Fish protein is composed of 20-30 \% sarcoplasmic composed of mainly albumins besides hemoproteins, 66-77\% myofibrillar such as myosin, actin, actomyosin and troponin and 3-5\% stromal proteins including collagens (Gates, 2016). Fish proteins have perfect water holding capacity and gelling capability supply peerless functional properties to fish processing industries (Taheri et al., 2013).

The fish protein is highly sensitive to deteriorative changes however under proper conditions, these changes causing loss of fresh quality can be prevented or delayed (Shahidi \& Simpson, 2004). During postharvest storage, activity of proteinases in fish tissue including high proportions of free amino acids and other non-protein nitrogenous constituents, reduction of trimethylamine oxide to trimethylamine, oxidative deamination of amino acids and peptides to ammonia and degradation of proteins may cause quality losses of products and limit the storage life (Lougovois \& Kyrana, 2005).

Fish and fish by-product proteins as well as enzymes which are key tools because of their catalytic nature are valuable in biotechnological applications of food industry (Fraatz et al., 2014; Jemli et al., 2016; Fernandes, 2016). In recent years, there has been an interest in recovering digestive enzymes from fish and shellfish processing discards for biotechnological applications in various sectors including acids for cheese making, herring fermentation, fish skinning, roe processing and production of specialty kits, as well as medical applications (Shahidi \& Kamil, 2001).

In this review, protein structure of fish, effects of processing methods on protein, some functional properties and biotechnological applications with the health effects on human nutrition are mentioned.

\section{Protein and Other Nitrogenous Compounds in Fish}

Since proteins affect both sensory properties and nutritional value of fish products, they constitute an important place in human health. Nine dietary essential amino acids including phenylalanine, histidine, leucine, lysine, threonine, iso- leucine, tryptophan, methionine and valine which are essential to the body and must be gotten by the diet are necessary for human. Fish and fish products' protein content is well suited for this purpose. Fish muscle has high proportion of proteins which are easily digestible and have lower collagen content leading to higher tenderness comparing to red meat (Savary-Auzeloux et al., 2014; Islam \& Joadder, 2005).

Food protein content generally is given as sum of both protein and NPN compounds (Sikorski, 2012). Nonprotein nitrogen (NPN) compounds including peptides, free amino-acids, amines, guanidine compounds, amine oxides, nucleotides, quaternary ammonium molecules, and urea are found mostly in the fiber sarcoplasm. Low molecular weighted non-protein nitrogenous compounds soluble in water like ammonia, dimethylamine, trimethylamine, free amino acids, creatine, nucleotides, and urea area existed in the cartilaginous fish. Some aquatic animals have relatively high percentage of NPN compounds comparing to the total nitrogen in the muscles whereas land animals generally have no more than $10 \%$ of total nitrogen. All these compounds have an effect on the sensory properties and play a significant role in the fish spoilage (Bandarra et al., 2001). Most marine fishes include trimethylamine oxide (TMAO) which is degraded to trimethylamine ensuing a 'fishy' odor and causes consumers not to prefer. Land animals and freshwater species (except for Nile perch and tilapia from Lake Victoria) does not involve this compound. Creatine one of the non -nitrogenous component in fish muscle form the major NPN fraction. Phosphorylated form of this molecule plays an important role in fish muscle metabolism (Caballero, 2005).

Fish are divided into four groups depending on the percentage of crude protein: below $10 \%, 10-15 \%, 15-$ $20 \%$, and over 20\% commercially (Sikorski, 2012). Studies revealed that variations occur in crude protein content depending on the variety, species, the state of nutrition, and the stage of the reproductive cycle of the animals. Boran \& Karaçam, (2011) studied four species including horse mackerel, garfish, golden mullet, and shad in the Black Sea in Turkey and reported that protein content varied between $13.0-19.8 \%$ among the species studied on fresh weight basis related to the physiological processes in the fish body during the reproductive activities. The protein content of horse mackerel, garfish, golden mullet and shad varied as $13.01-18.60 \%, 13.99-18.45 \%, 13.31-17.20 \%$ and $14.30-$ $19.80 \%$ respectively. The authors reported that when the average values were considered, the lowest protein content was in horse mackerel with $14.78 \%$ and the highest content of protein was in garfish with $16.89 \%$.

Islam \& Joadder, (2005) determined the protein content of $G$. giuris seasonally and reported that it varied from $14.09 \%$ (February) to $16.03 \%$ (August) in male individuals. Similarly, females had $13.88 \%$ of 
protein conten in February and $15.56 \%$ in November. They explained that, the protein content was low in the spawning season both in male and female where the average protein content of the female $(14.61 \%)$ was lower than the male (15.23\%).

\section{Sarcoplasmic and Myofibrillar Proteins}

Proteins composed of sarcoplasmic or myogen fraction of the muscle which have low molecular weight in the range of 40,000 to $70,000 \mathrm{kDa}$ are soluble in water and dilute salt solution. Pelagic fish species like anchovy, sprat and horse mackerel have higher fractions of sarcoplasmic proteins comparing with demersal fish species like turbot, flounder etc... In general, white muscle of some fish species contain more sarcoplasmic proteins than dark muscles. Comparing with land animals, sarcoplasmic protein of fish incorporates myoglobin, albumins and enzymes where fish species from cold water oceans include antifreeze proteins and glycoproteins classified also in sarcoplasmic protein group (Shahidi \& Botta, 2012). Enzymes especially glycolytic enzymes participating in the cell metabolism are the most found proteins in the sarcoplasmic proteins. Most fish species include heat-stable proteolytic enzymes, such as cathepsin in order to bind to the myofibrillars (Lanier, 2000). Many sarcoplasmic proteins are globular which are expected to bind more water upon denaturation. Sarcoplasmic proteins, consequently, has effects on water holding capacity (Wilson \& Laack, 1999). The further group of sarcoplasmic proteins are the heme proteins that effect lipid oxidation and postharvest color change (Kim, 2002). In cold waters some fish species have proteins which are identified as antifreeze glycoproteins that lower freezing temperature (Sikorski, 2012).

Myosin, tropomyosin, actin, and the troponins T, C, and $\mathrm{I}$ regulating muscle contraction are myofibrillar proteins. Adenosine triphosphate (ATP) is broken down into adenosine diphosphate (ADP) to provide the chemical energy required for muscle contraction by catalyzing of myosin ATPase activity (Listrat et al., 2016). The myofibrillar proteins of fish muscle are less stable in terms of thermal properties than those from mammalian muscles. Their stability depends on the fish species, habitat temperature, ionic strength and $\mathrm{pH}$ like in vitro properties of the proteins (Poulter et al., 1985).

\section{Changes in Protein in Frozen Stored and Heat - Induced Fish}

Fish stored at about $-20^{\circ} \mathrm{C}$ can be remain for several months without losing its flavors. However, solubility, water retention, lipid emulsifying properties and some other functional characteristics like gelling ability of muscle proteins can be changed.

Mitochondria and lysosomes lysis may occur after freezing and thawing process which can be lead to an alteration in enzyme distribution (Karvinen et al., 1982).
Freeze denaturation of proteins is the main reason for this change which follows the interactions between constituents of fish tissues and the denatured proteins. Denaturation of proteins, oxidation, re-crystallization of ice crystals and sublimation can cause quality losses of frozen fish (Haard, 1991). Protein denaturation contributes to increase of drip loss leading mineral content diminish, loss of water holding capacity and textural changes (Nakazawa \& Okazaki, 2020).

Heating the frozen fish needs time and temperature control in order to obtain products similar to unfrozen ones (Giang et al., 1989). The heating process can lead reabsorbed of the water by the tissues and relation to ice crystals sizes and locations the structure of flesh can be changed. If the fish is not properly frozen and thawed, the protein will aggregate and water loss occurs during the thawing which cause hard product in texture (Nakazawa \& Okazaki, 2020).

Rate of enzymatic processes are affected by the heating; it causes denaturation and resultant interactions of proteins increase chemical interactions of different tissue constituents. Thus, color and rheological properties of thawed fish fillets change and lose their water-retention capacity also develop some desirable flavor characteristics (Sikorski \& Ruiter, 1994). Endogenous and bacterial enzyme inhibition by heating is the main purpose of the fish processing industry on the contrary of other food industries. Heating destroys activity of enzymes in fish easily. Sarcoplasmic proteins among other three muscle proteins do not affect the functional properties significantly. They are not main component of the histological structure of the tissues and can lose solubility easily when heated. Nevertheless, glyceraldehyde-3-phosphate dehydrogenase and aldolase like glycolytic enzymes have important effects on the rheological properties of fish gels. Toughness of the fish fillet can be increased by the thermal changes of the myofibrillar proteins and tenderness of the fish can be affected by the heated collagen transformation (Sikorski et al., 1990). Only mild heating is required because of the muscle structure of fish and the low content of collagen so that the resultant loss of nutritional value is not high (Aitken \& Connell, 1979). In heating under some conditions may lead to the formation of different maillard products in seafood, and this can result with loss of nutritive value (Dworschak, 1980 ). Frying process of fish for about $4 \mathrm{~min}$ in fresh oil at $180^{\circ} \mathrm{C}$ may decrease the available lysine by about $18 \%$. When highly oxidized oil is used, the loss is about 29\% (Tooley \& Lawrie, 1974). The effect of heat on nitrogenous components of fish may have also a food safety aspect because heating may serve to inactivate marine toxins (Gill et al., 1985).

\section{Effects of Processing Methods on Proteins}

To extend the shelf life and improve the quality properties of fish canning, salting, drying, smoking and fermenting methods are used for decades (Figure 1). 
Combined effects of low water activity, inhibition of bacterial growth, preservative effects of some chemicals and acetic acid, antioxidant and antibacterial effects of some smoking constituents develop extended storage life of fish products.

In salted fish, preservation is occurred due to the dry salt or brine which changes protein in result of effects of salt on proteolytic enzymes. The salt used for fish should not be finely grained due to rapid dissolving activity of the salt in the muscle and cause rapid withdrawal of moisture from the surface tissue. So that, protein denaturation occurs due to prevention of the penetration of the salt into the muscle known as "salt burn". This denaturation is generally proceeding slower than the penetration of salt in normal conditions (Tülsner, 1978). Ion-exchanging properties of proteins is another relevant issue which one of the effects of the salt. To obtain a soft and mushy texture of the fillet, $\mathrm{Ca}^{2+}$ and $\mathrm{Mg}^{2+}$ ions in the muscles should be substituted by the $\mathrm{Na}^{+}$from the brine. As this process is reversible, tough product may be obtained by accumulation of $\mathrm{Mg}^{2+}$ and $\mathrm{Ca}^{2+}$ from impure salt in the flesh (Sikorski, 2012).

In Southeast Asia, fermented fish sauce and paste are very common products consumed as a source of nutrients. Generally, whole, ungutted salted fish, is used for production of fish sauce or paste and protein hydrolysis plays a major role which amino acids' proteolysis decarboxylation occurs in achieving the desirable sensory properties (Ciou et al., 2020).

Canning is one of the most important preservation techniques used in food industry including fish processing. In fish canning process, it is not recommended to canning process of lean fish due to their flesh disintegrate under the high temperature leading to texture and flavor lost. The preservation object is to inactivate the endogenous enzymes activity and reduce the moisture content. As a result of high temperature $\left(121^{\circ} \mathrm{C}, 15 \mathrm{~min}.\right)$, proteins, vitamins, minerals and lipids go under alteration and sometimes nutritional and sensory values of these products could be reduced due to the formation of undesirable compounds (Aubourg, 2001).

Solar drying is one of the techniques to reduce water content whereby bacterial growth is inhibited mostly. Lower drying rate $(1 \mathrm{~m} / \mathrm{s})$ has a negative effect on protein content. In natural drying, fish dries faster and becomes harder although still some moisture remains inside which leads the drying process occurs slowly and cause protein degradation. Also, extremely prolonged solar drying cause oxidize the lipids and nutritional value losts (Abraha et al., 2018).

Smoking which provides antimicrobial smoking agents like phenols and formaldehydes to preserve the fish fillets is used for centuries for both preservation and flavoring. Smoking has reduced water activity effect by the heat which allows fish to be prevented from microbial spoilage. During the smoking process, temperature, type of wood and time must be controlled in order to obtain a high-quality resultant product. Basically, there are two types of smoking, hot and cold smoking. During smoking process, proteins and amino acids will be denatured depending on the intensity of heat applied. Overheating may lead to loss of availability of essential amino acids like tryptophan, lysine and methionine (Adeyeye, 2019).

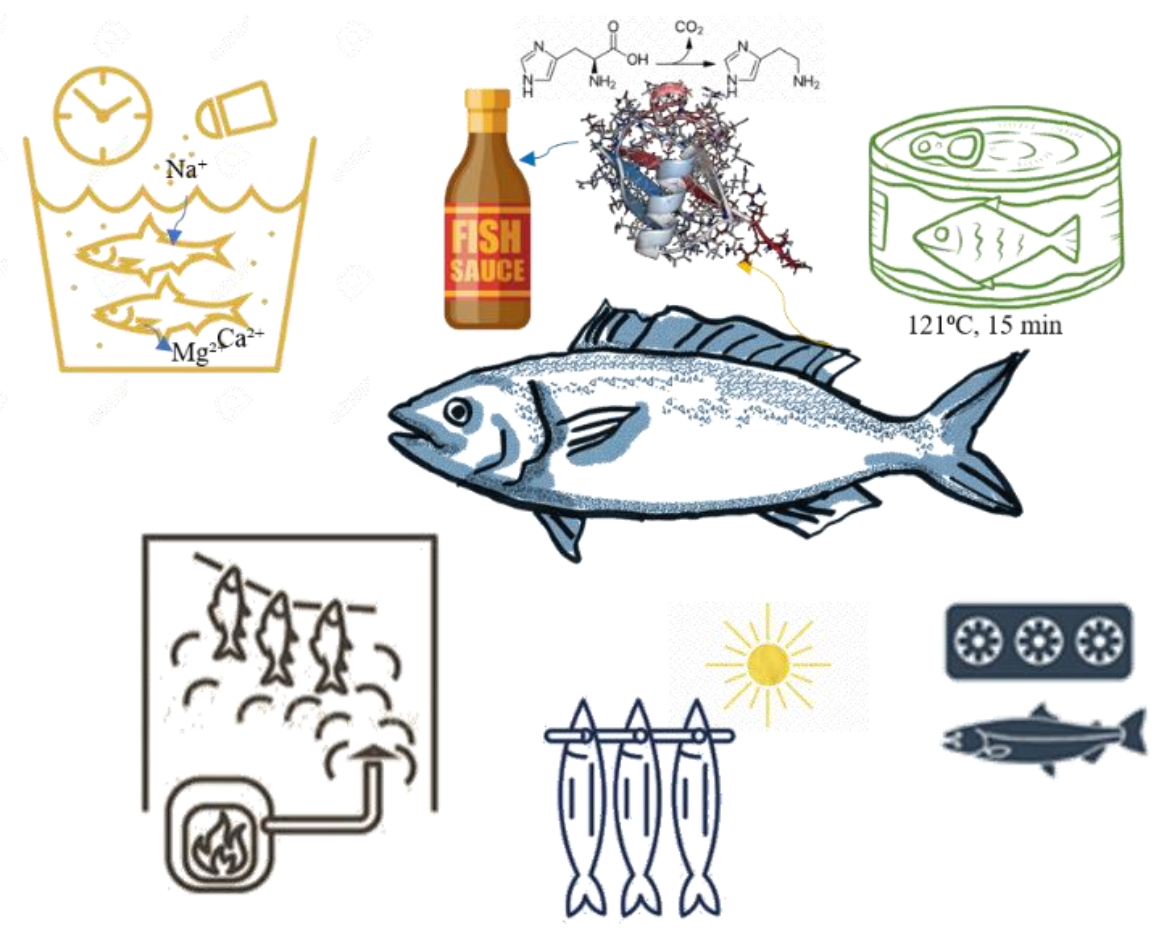

Figure 1. Fish processing methods 
Fish Protein as a Functional Food Ingredient and Biotechnological Applications

The term "functional property" means the ingredients which lead to the appearance, texture and taste of a food. Isolating fish proteins for using in other types of foods as ingredient begins with the production of minced or mechanically deboned fish. This is also the common step of surimi production. Fish minces have functional advantages exhibiting a meat like texture than other type of meat minces like mammalian and poultry meats. Minced muscles from lean fish species are generally less functional interms of gelling capability than surimi (MacDonald et al., 1990), and also its constancy in frozen conditions is poor due to high capacity of enzyme activity (Suzuki, 1981). Fatty fish species are not stable in storage too due to potential of spoilage by oxidation of the lipids (Hultin, 1987; Shenouda, 1980).

Fish hydrolysates have been used as flavoring compounds, generally as fish sauce in the Eastern countries for centuries. This product is now also popular in Western countries as Eastern cooking techniques become widely known. Poor functional properties and solubility are the main disadvantages of the fish protein concentrates (FPC) (Meyer, 1965; Holden, 1971). The proteins are denatured highly to form gel even when solubilized by alkali treatment (Tannenbaum et al., 1970), although reasonable foaming characteristic have been indicated (Baldwin \& Sinthvalai, 1974).

Surimi is produced from minced fish such as underutilized species with little or no commercial value to provide opportunities to use different sources of protein. Wet concentrate of high-quality myofibrillar proteins from raw minced fish flesh are salt-solubilized and heated to generate surimi hydrogel. Alaska Pollock is used mostly in surimi production due to its good gelation properties, white color and desirable odor (Luo et al., 2001).

Fish gelatins obtained from the cold-water fish species are less vulnerable to gel when comparing with the those from mammalians but are excellent filmforming agents, crystal growth inhibitors and emulsion stabilizers (Norland, 1990). Fish gelatins are one of the succeed fish protein ingredient that take place in the marketing. Moreover, they can be used instead of mammalian gelatins where religious prohibitions exist (Karim \& Bhat, 2009).

Marine biotechnology is a growing field that takes place in product chemistry, molecular biology, comparative biochemistry and gene technology. Recovery and/or transformation of "value-added" products from marine organisms is one of the main objectives of marine biotechnology. For instance, specific surfactants, emulsifiers, pharmaceuticals and flavorings can be obtained by treating the fish protein with particular proteinases. Natural products derived from marine organisms like vaccines, enzymes, antifreeze proteins, antibiotics, hormones and amino acids can have incomparable properties (Figure2). Industrial enzymes used in the depolymerization of natural substances are all almost hydrolases. Production of industrial enzymes are based on two methods (1) extraction from animal or plants and (2) microbial fermentation. Enzymes obtained from the fish processing waste or by-products are usually utilized by the industrial applications (Raa, 1990; Haard, 1991).

Egg albumin can be replaced by the those derivated from crustaceans, mollusks and low-fat fish (Ockerman \& Hansen, 1988). Also, cattle pancreas is the main source for the extraction of insulin used in the diabet treatment. However, insulin isolated from fish can be also used as a replacement of bovine pancreas with its more stable properties (Sanlioglu et al., 2013).

\section{Fish Protein in Human Nutrition and Health Effects}

The value of fish proteins is as high as meat protein and inferior to milk and egg protein. Fish protein has a stable composition of essential amino acids, with slight deficiencies of methionine and threonine, and an excess of lysine which is limited in cereals (Lozano \& Hardisson, 2003). Fish protein includes essential amino acids such as tryptophan, cystine, lysine, methionine, and threonine which improves the digestibility. Aquatic protein contains essential amino acids and peptides much more than terrestrial meat protein such as lysine and methionine (Khan et al., 2020). Fish has health benefits with its high-protein, low-fat content. In particular, white-fleshed fish, is lower in fat than any other source of animal protein, and oily fish are high in omega-3 fatty acids. Since the human body must supply these essential nutrients, fish are an important part of the diet. Also, fish are low in the "bad" fats commonly found in red meat, called omega- 6 fatty acids (Schaafsma, 2008). Fish proteins are consisted of several peptides having functional properties which are beneficial for human health. These peptides show many biological activities such as antioxidant, anti-diabetic, anti-proliferative, antimicrobial, anti-coagulant, antihypertensive, and calcium-binding activities, thereby, improving the health (Khan et al., 2020).

Protein is required for the construction of several essential compounds such as antibodies, enzymes, hormones and utilized for the structural formation of tissues and cells in the body. One of the main energy sources of our body is the protein content (1 $\mathrm{g}$ of protein provides $4 \mathrm{kcal}$ ). Infants, children, and pregnant women need dietary protein for depositing new protein in tissues and for the continuation of protein synthesis in adults' body. Therefore, inadequate protein intake can result in diminished protein content in cells and organs and deterioration in the cellular capacity to perform normal functions. This leads to increased morbidity and mortality. On the other hand, excess protein intake is also disadvantageous (Young \& Pellet, 1987). Therefore, an appropriate level of protein content is needed for an adequate diet for the assurance of long-term health. 


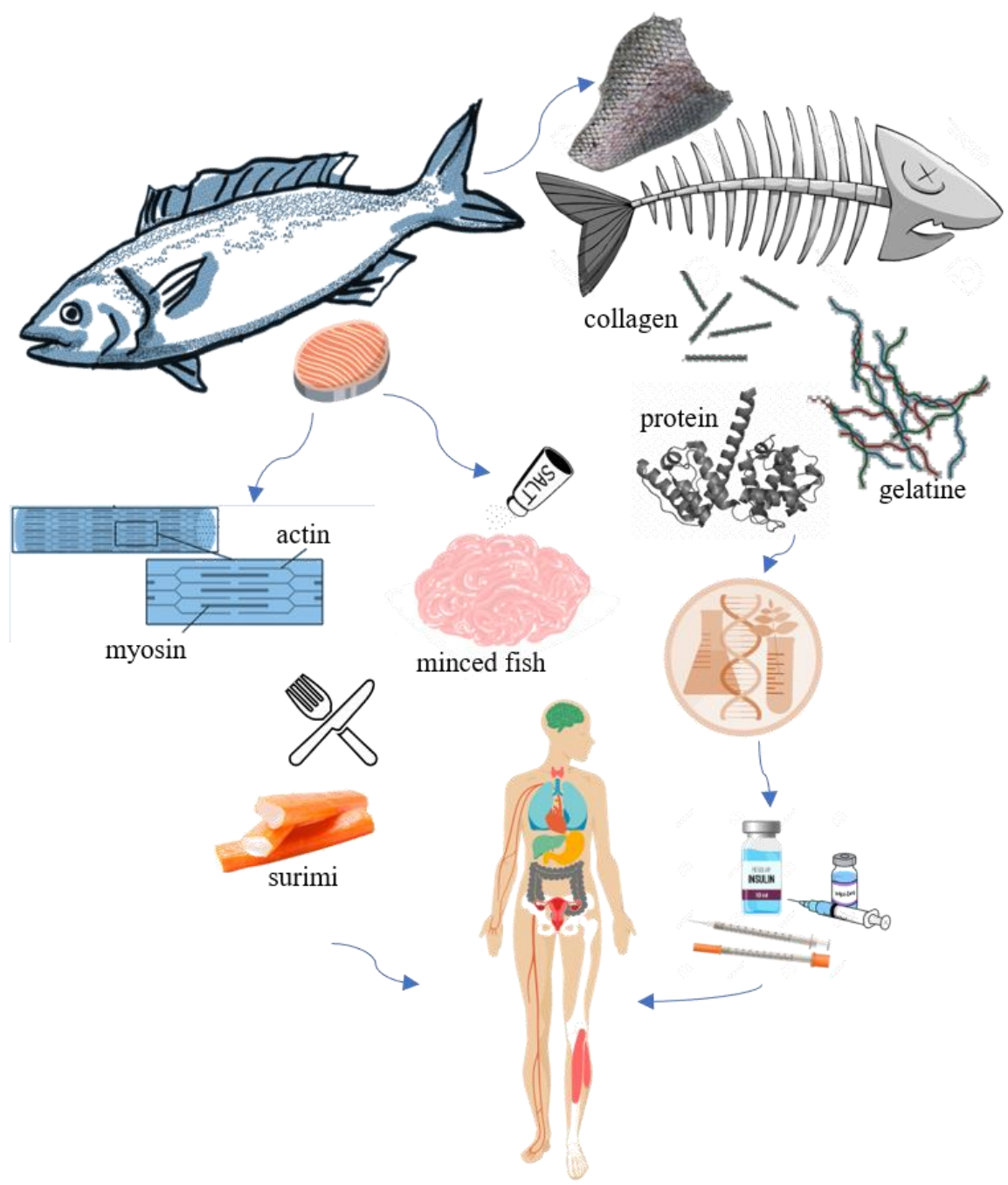

Figure.2. Utilization of fish by-products

One of the causes of death in children in developing countries is protein calorie malnutrition. Adults or children who have insufficient intake of protein or not be able to convert the vital nutrient to energy required for healthy tissue formation and proper organ function can have protein calorie malnutrition. As the insufficient intake of protein continues, loss of muscle mass, decreased immunity, and growth failure can be observed in the patient. Fish has a greater satiety effect comparing to other animal protein sources and is also more affordable when many varieties of fish species is concerned in the tropical countries (Mohanty et al., 2019). Apart from their health effects, gelatine and collagen sort of fish protein are used in cosmetic industry with their fabulous moisturizing properties as anti-aging and anti-wrinkle (Guaadaoui et. al., 2014).

\section{Author Contribution}

Esen Alp Erbay: Conceptualization, writing original draft, editing.

Ahmet Faruk Yeşilsu: Conceptualization, writing original draft.

\section{Conflict of Interest}

The authors declare that they have no known competing financial interests or personal relationships that could have appeared to influence the work reported in this paper.

\section{References}

Abraha, B., Admassu, H., Mahmud, A., Tsighe, N., Shui, X.W., \& Fang, Y. (2018). Effect of processing methods on nutritional and physico-chemical composition of fish: a review. Food Processing \& Technology, 6(4), 376-382.

Adeyeye, S.A.O. (2019). Smoking of fish: A critical review. Journal of Culinary Science \& Technology, 17(6), 559575.

Aitken, A. \& Connell, J. (1979). Fish. In: Priestley R (ed) Effects of heating on food stuffs. Applied Science Publishers Ltd, London (UK), pp 219-254.

Aubourg, S.P. (2001). Loss of quality during the manufacture of canned fish products. Food Science and Technology International, 7(3), 199-215.

Baldwin, R.E., \& Sinthavalai, S. (1974). Fish Protein Concentrate Foam. Food Sci. 39:880-882.

Bandarra, N., Calhau, M.A., Oliveira, L., Ramos, M., Da Graça Dias, M., Bartolo, H., Faria, M.R., Fonseca, M.C., 
Gonçalves, J., Batista, I., Nunes, M.L., (2001). Composition \& Nutritional Value of Seafood Consumed in Portugal \& Evaluation of Biological Effects of Fish Oils. Within the Project POCTI/1747/95/2001. IPMA, Instituto de Investigação das Pescas e do Mar (IPIMAR), Instituto Nacional de Saúde Dr. Ricardo Jorge (INSA) \& Fundação para a Ciência e Tecnologia (FCT) retrieved from: https://www.ipma.pt/resources.www/docs/publicacoe s.site/pescado/site/introducao/proteins.htm

Boran, G., \& Karaçam, H. (2011). Seasonal changes in proximate composition of some fish species from the Black Sea. Turkish Journal of Fisheries \& Aquatic Sciences, 11(1). https://doi.org/10.4194/trjfas.2011.0101

Caballero, B. (2005). Encyclopedia of human nutrition. Elsevier.

Ciou, J.Y., Hsieh, L.S., Lee, T.T., \& Hsieh, C.W. (2020). Enhancement of Agricultural Processed By-Products: Qualities Analysis of Fermentation Method in Gradient Salt Adding Treatment of Tuna Cooking Juice with Black Bean Koji Added. Foods, 9(3), 320.

Dworschak, E., \& Carpenter, K.J. (1980). Nonenzyme browning $\&$ its effect on protein nutrition. Critical Reviews in Food Science \& Nutrition, 13(1), 1-40. https://doi.org/10.1080/10408398009527283

FAO, 2020. The Satate of World Fisheries \& Aquaculture. Sustainability in Action.

Fernandes, P. (2016). Enzymes in fish \& seafood processing Frontiers in bioengineering \& biotechnology, 4.

Finch, R.A., \& Liston, J. (1970). Fish Protein for Human Foods. Critical Reviews in Food Science \& Nutrition, 1(4), 519580. https://doi.org/10.1080/10408397009558516

Fraatz, M.A., Rühl, M., \& Zorn, H. (2014). Food \& feed enzymes. Adv. Biochem. Eng. Biotechnol. 143, 229-256. https://doi.org/10.1007/10_2013_235

Gates, K.W. (2016). Seafood Science: Advances in Chemistry, Technology \& Applications, Edited by Se-Kwon Kim: CRC Press. Taylor \& Francis Group. Boca Raton, FL, USA. 2015. ISBN 978-1-4665-9582-8. 606 pages.

Guaadaoui, A.; Benaicha, S.; Elmajdoub, N.; Bellaoui, M.; Hamal, A.; Elsohaimy, S.A.; Refaay, T.M. What is a Bioactive Compound? A Combined Definition for A Preliminary Consensus. Int. J. Nutr. Food Sci. 2014, 3(3), 174-179. https//doi.org/10.11648/j.ijnfs.20140303.16.

Haard, N. (1991). Fish Protease in Food Industry. Memorias Del Segundo Simposium En Biotecnologia Marina. La Paz, BCS, Mexico. Revista de la Sociedad Mexicana de Biotecnologia y Bioingenierfa. AC. 1(4), 4-16.

Harnedy, P.A. \& FitzGerald, R.J. (2012) Bioactive peptides from marine processing waste \& Shell fish: a review. J Funct Food 4:6-24. https://doi.org/10.1016/j.jff.2011.09.001

Holden, C. (1971). Fish flour: protein supplement has yet to fulfill expectations.

Hultin, H.O. (1987). Factors Responsible for Lipid Oxidation in Fish Muscle. Pp. 185-224. In Proc. Conf Fatty Fish Utilization: Upgrading from Feed to Food. University of North Carolina, Raleigh, NC, SeaGrant Publ. 88-04.

Islam, M.N., \& Joadder, M.A.R. (2005). Seasonal variation of the proximate composition of freshwater Gobi, Glossogobius giuris (Hamilton) from the River Padma. Pakistan Journal of Biological Sciences, 8(4), 532-536.

Jemli, S., Ayadi-Zouari, D., Hlima, H.B., \& Bejar, S. (2016). Biocatalysts: application \& engineering for industrial purposes. Crit. Rev. Biotechnol. 36, 246-258. https://doi.org/10.3109/07388551.2014.950550

Karim, A.A., \& Bhat, R. (2009). Fish gelatin: properties, challenges, and prospects as an alternative to mammalian gelatins. Food hydrocolloids, 23(3), 563-576.

Karvinen, V.P., Bamford, D.H., \& Granroth, B. (1982). Changes in Muscle Subcellular Fractions of Baltic Herring (Clupea harengus membras) During Cold \& Frozen Storage. Journal of the Science of Food \& Agriculture, 33(8), 763 770. https://doi.org/10.1002/jsfa.2740330813

Khan, S., Rehman, A., Shah, H., Aadil, R.M., Ali, A., Shehzad, Q. ... \& Xia, W. (2020). Fish Protein and Its Derivatives: The Novel Applications, Bioactivities, and Their Functional Significance in Food Products. Food Reviews International, 1-28.

Kim, Y.S. (2002). Physicochemical characteristics of fish myofibrillar \& sarcoplasmic proteins treated at various $\mathrm{pH}$ conditions (Doctoral dissertation).

Lanier T.C. (2000). Surimi gelation chemistry. Park, JW (ed), New York, NY: Marcel Dekker Inc. 239p, 249-250pp.

Lozano, G. \& Hardisson, A. (2003). Fish as Food. University of La Laguna, Tenerife, Canary Islands, Spain, Elsevier Science.

Listrat, A., Lebret, B., Louveau, I., Astruc, T., Bonnet, M., Lefaucheur, L., ... \& Bugeon, J. (2016). How muscle structure \& composition influence meat \& flesh quality. The Scientific World Journal.

Lougovois, V.P., \& Kyrana, V.R. (2005). Freshness quality \& spoilage of chill-stored fish. Food Policy, Control \& Research, 35-86. ISBN 1-59454-408-5.

Luo, Y.K., Kuwahara, R., Kaneniwa, M., Murata, Y., \& Yokoyama, M. (2001). Comparison of gel properties of surimi from Alaska pollock and three freshwater fish species: effects of thermal processing and protein concentration. Journal of Food Science, 66(4), 548-554.

Macdonald, G.A., Lelievre, J., \& Wilson, N.D.C. (1990). Strength of Gels Prepared from Washed \& Unwashed Minces of Hoki (Macruronus novaezelandiae) Stored in Ice. Food Sci. 55:976-978. https://doi.org/10.1111/j.1365-2621.1990.tb01578.x

Majumdar, R.K., Roy, D., Bejjanki, S., \& Bhaskar, N. (2016). An overview of some ethnic fermented fish products of the Eastern Himalayan region of India. Journal of Ethnic Foods, 3(4), 276-283. https://doi.org/10.1016/j.jef.2016.12.003

Meyer, V. (1965). Uber die Bedentung proteolytischer Fermunte bei der Herstellung Nichsterilizierter Fischwaren. Archiv fur Fishere-iwissenschaft, 15, 245.

Mohanty, B.P., Ganguly, S., Mahanty, A., Mitra, T., Patra, S., Karunakaran, D., ... \& Ayyappan, S. (2019). Fish in human health and nutrition. Advances in fish research, 7, 189218.

Nakazawa, N., \& Okazaki, E. (2020). Recent research on factors influencing the quality of frozen seafood. Fisheries Science, 86(2), 231-244.

Norland, R.E. (1990). Fish Gelatin. In Advances in Fisheries Technology \& Biotechnology for Increased Profitability. Edited by M.N. Voigt \&. R. Botta. Lancaster, PA: Technomic Publishing Co. pp. 325-333.

Ockerman, H.W. \& Hansen, C.L. (1988). Animal by-product processing. Weinheim: VCH; Chichester: Horwood.

Poulter, R.G., Ledward, D.A., Godber, S., Hall, G., \& Rowlands, B. (1985). Heat stability of fish muscle proteins. International Journal of Food Science \& Technology, 20(2), 203-217.

Raa, J. (1990). Biotechnology in aquaculture \& the fish processing industry: A success story in Norway. Advances in fisheries technology \& biotechnology for 
increased profitability, 509-524.

Sanlioglu, A.D., Altunbas, H.A., Balci, M.K., Griffith, T.S., \& Sanlioglu, S. (2013). Clinical utility of insulin and insulin analogs. Islets, 5(2), 67-78.

Savary-Auzeloux, I., Mosoni, L., Rémond, D., Dardevet, D., \& Boirie, Y. 2014. Protein Digestion, Absorption \& Metabolism.

https://www.researchgate.net/publication/260626860 _Protein_Digestion_Absorption_\&_Metabolism

Schaafsma, G. (2008). Introduction to Part II: Health benefits of seafood. Improving seafood products for the consumer, 113-115.

Shahidi, F. \& Kamil, Y.V.A.J. (2001). Enzymes from fish and aquatic invertebrates and their application in the food industry. Trends Food Sci. Technol. 12: 435-464. https://doi.org/10.1016/S0924-2244(02)00021-3

Shahidi, F., \& Botta, J.R. (2012). Seafoods: chemistry, processing technology \& quality. Springer Science \& Business Media.

Shahidi, F., \& Simpson, B.K. (Eds.). (2004). Seafood quality \& safety: Advances in the new millennium. DEStech Publications, Inc.

Shenouda, S.Y. (1980). Theories of protein denaturation during frozen storage of fish flesh. In Advances in food research (Vol. 26, pp. 275-311). Academic Press.

Sikorski, Z. (2012). Seafood proteins. Springer Science \& Business Media.

Sikorski, Z.E. (1990). Fish: Resources, Nutritional Composition, \& Preservation. CRC press.

Sikorski, Z.E., \& Ruiter, A. (1994). Changes in Proteins \& Nonprotein Nitrogen Compounds in Cured, Fermented \&
Dried Fishs. Fish proteins. Chapman \& Hall, New York, 113-126.

Suzuki, T. (1981). Fish \& Krill Protein: Processing Technology. London: Applied Science Publishers.

Taheri, A., Anvar, S.A.A., Ahari, H., \& Fogliano, V. (2013). Comparison the functional properties of protein hydrolysates from poultry byproducts and rainbow trout (Onchorhynchus mykiss) viscera. Iranian Journal of Fisheries Sciences, 12(1), 154-169.

Tamang, J.P. (Ed.). (2015). Health benefits of fermented foods \& beverages. CRC Press.

Tannenbaum, S.R., Ahern, M., \& Bates, R. (1970). Solubilization of fish protein concentrate. 1. an alkaline process. Food technology.

Tooley, P.J., \& Lawrie, R.A. (1974). Effect of deep fat frying on the availability of lysine in fish fillets. International Journal of Food Science \& Technology, 9(2), 247-253. https://doi.org/10.1111/j.1365-2621.1974.tb01768.x

Tülsner, M. (1978). Die hestimmenden stofflichen Veränderungen im Fisch beim Salzen und Marinieren. Lebensmittelindustrie 25(4): 169-173.

URL-1. http://www.fao.org/3/v7180e/V7180E05.htm

Wilson, G.G., Laack, R.L (1999). Sarcoplasmic proteins influence water-holding capacity of pork myofibrils. J Sci Food Agric 79: 1939-1942.

https://doi.org/10.1002/(SICI)10970010(199910)79:13<1939: AID-JSFA469>3.0.CO;2-T

Young, V.R., \& Pellett, P.L (1987). Protein intake and requirements with reference to diet and health. The American Journal of Clinical Nutrition, 45(5), 1323-1343. https://doi.org/10.1093/ajcn/45.5.1323 